\title{
The Use of Delphi method as a Tool to improve Tourism Strategy in Egypt Marwa Fawzi Abdel Warith
}

\author{
Tourism Studies Department, Sadat City University
}

\begin{abstract}
This paper presents the results of a three round Delphi survey conducted into experts' opinion on the tourism strategy to measure the efficiency of the Refreshed Tourism Strategy 2013-2020 for tourism in Egypt. For the achievement of this purpose, the Delphi method was used. The results of this experts' survey shown considerable agreement over the efficiency of these elements for the Refreshed Tourism Strategy. However, they pointed to lack of a niche tourism offer, problems with the implementation of innovative products/services/technologies, and lack of training for employment and skills development strategies. In addition, the research identified measures to implementation such as adapting the educational system and lifelong learning to the needs of the tourism industry, strengthening the support of local, regional, and international authorities, and development of infrastructure, including transport infrastructure.
\end{abstract}

Keywords: Delphi method, Egypt, Tourism Strategy, Refreshed Tourism Stratgy

\section{Introduction}

The Egyptian tourism industry is a key for accomplishing economic growth, increase employment, providing foreign currency and for linkages with other monetary parts. In spite of the recession that this industry saw during the last recent 4 years, it can revive the current situation, while maintaining the political stability and security. Investment opportunities contribute to the growth of the tourism sector and attract tourism investments, expanding its share of GDP and making more occupations. These targets are adjusted to the Sustainable Development Strategy (SDS) objectives and key performance indicators (KPIs) of building an expanded economy that incredibly relies on upon administrations. The tourism industry is relied upon to contribute essentially to financial goals as indicated by SDS, particularly with the applying green tourism, responsible tourism and sustainable tourism (Government of Egypt, 2015).

Egypt is a key political and financial player in Africa, attract different peoples, larg tourism investments and assistance programs for the development from all parts of the world. However, the country faces many environmental and political challenges and still receives foreign aid. The Egyptian tourism industry is characterized by the diversity of tourism product all over the world. Egypt has bright pristine beaches along the ancient and diverse cultural heritage and history. Morover, the geographical location has made it a destination for adventure tourism, environmental, sailing, diving, health and cultural tourism and religious tourism for Christians and Muslims (Swiss Economic Cooperation and Development, 2012). 
As indicated by Egypt's tourism vision, the government is continued to keep supporting a market, competitive, enhanced, information based, and privatesector drove economy, illustrated by a stable macroeconomic environment, maintainable comprehensive development, maximizing value added, and increasing job opportunities. By 2030, the Egyptian economy will be a dynamic player on the economy, equipped for conforming to universal improvements and very much situated to join the positions of the world's medium-income countries. Furthermore, The Sustainable Development Strategy (SDS): Egypt 2030 goes for making an advanced, open, law based, productive, and glad society. A participatory arranging methodology was received to set up the SDS. The common society associations and the private sector were driving this procedure, to guarantee the authorization and implementation of the strategies, projects, and activities that will be embraced to accomplish the objectives of the system. A complete monitoring and evaluation (M\&E) framework will be set up to nearly watch the execution of the SDS, evaluate its effect and regularly measure the advance towards accomplishing the fundamental objectives of the methodology and the diverse key performance indicators (KPIs) (Government of Egypt, 2015). Therefore, there is one approach to manage the relationship between local communities and tourism, it is part of the safety and security issues to take LE50 (per head) from tourism profits and pumped to the community in the form of services. Such a tourism social fund could help with education, leisure, water/sanitation, health or support people to finish rites of pilgrimage. All of these benefits resulting from tourism (Egyptian national competitiveness council, 2013).

The success of the implementation of the tourism startegies depends on the competences of the provincial government. Through the adoption of local development, strategies and programs of the provinces and spatial development plan with the region's budget and determine the rules of distribution of grants (Kiryluk, 2009). Consequently, the aim of the tourism development strategy is to create destination strategy and action plan. This plan is characterized by being specific in terms of the form of the product and the visitors experience; it will provide and support niche marketing. The priorities will be determined within the destination in terms of development and marketing, besides, planning and growth of the social and economic aspects. It is planned from the beginning that each sub-destination will have a full-service airport, allowing direct international air access. Each sub-destination has a complete freedom to develop its brand and marketing, but with an emphasis on integration with the national brand and participation in the activities of international marketing under the banner of Egypt as a mega destination (Egyptian national competitiveness council, 2013).

The purpose of this paper is to indicate the use of the Delphi method in the process of measuring the efficiency of the Refreshed Tourism Strategy 20132020 for developing and improving tourism in Egypt. The refreshed strategy provides strategic guidance on all the critical essentials for Egypt to adopt, in order to attain its economic and social purposes, and to recover a sustainable growth path as quickly as possible; depending upon nine themes or factors 
methodologies, concepts, and best practices that are essential to Egypt achieving its tourism goals. To improve the process of preparing a strategy for tourism, and later also increase the level of its implementation, the author proposes to integrate the Delphi method with the process of strategy formulation, thanks to which the process will involve the widely understood experts and stakeholders of the tourism industry in Egypt. Furthermore, the research focuses on answering two questions: (1) what is Delphi method? (2) How can we use Delphi method to measure the efficiency of the Refreshed Tourism Strategy 2013-2020 for developing and improving tourism in Egypt?

\section{Literature review}

\subsection{Egyptian Tourism Strategy 2013-2020}

Egypt that will expand on its characteristic qualities and possibilities in a way that focuses on the client and what he needs. The inherent welcome of the Egyptian individuals will be combined with positive way of life components, including mix of the cultures and heritage of Europe, Arabia, Asia, and Africa. The target will be to improve the guest encounter through a multi tactile approach (Egyptian national competitiveness council, 2013). Moreover, Egypt has a key geopolitical part with the Suez Canal under its control, and given its focal area in the Arab world. Egypt holds a key part in African, Mediterranean, Middle Eastern, and even worldwide governmental issues. Cairo has been at the junction of provincial business and culture for a considerable length of time, and its scholarly and Islamic establishments are at the focal point of the locale's social and social advancement (Swiss Economic Cooperation and Development, 2012).

Additionally, The Ministry of Tourism implements motivated strategy to strengthen the sector by diversifying tourism products; developing new markets; and enhancing private sector investments. The government's strategy in the sector relies on five main policy actions: (Government of Egypt, 2015)

- A marketing strategy implements a proactive campaign to reposition Egypt as a mega destination.

- Enhancing cultural destinations, facilitating infrastructure, and connections with other destinations. The development of the Pyramids area, tourism facilities, and the Egyptian Grand Museum project will encourage both luxury and cultural tourism in the region and considerably boost the number of visitors per year.

- Improving the skills of the employment force will allow in turn attracting higher value-added tourism. Wide-ranging training programs will be set up to help profitability in the sector and reward for the reduction in talented work.

- Developing the tourism sector's value chain through the creation of SMEs that attract tourism providers such as restaurants and leisure activities.

- Harmonizing and facilitating land and allow allocation processes for new development projects. A national map for land portion is being readied and the government plans to assure sustainability. 
One fundamental challenge will be to re-plann and re-evaluate the transparent and fair macroeconomic strategy to enhance Egypt's general financial shortage and recover crisis that left after the revolution. Assist measures to handle other macro economic difficulties, for example, price raises, large subsidies, large domestic debt, intensification of the tax system and the restructuring of treasury management. As a rule, executing basic changes requires a strong cooperation between all the partners on the medium and long haul advantages. (Swiss Economic Cooperation and Development, 2012). Furthermore, tourism industry supports the improvement of economy. However, Egypt's tourism industry has indicated strong variations in international tourism arrivals since 2009. In the first quarter of 2014, tourism income is estimated to have dropped a huge $43 \%$, which contributes more than 10\% to GDP (Sleiman, 2014). In order to support the flexibility of demand from North American, European, and other long haul markets that comprise $70 \%$ of total international visitation, the Egyptian Tourism Ministry started a cross-platform marketing campaign targeted at short haul markets in the Gulf Cooperation Council (GCC) around the vital occasions of Eid and Ramadan. Moreover, Arab guests are seen as higher-spend voyagers than different markets that are most value delicate and traveling on packaged tours. With the campaign, it is predictable that the visitors would pay out money shopping, dining, and enjoying the luxury amusement experiences that could support the economic recovery needed during the off-season in tourism (COMCEC, 2015).

\subsection{The Refreshed National Tourism Strategy}

This is a "refreshed version" of the 2008/9 National Tourism Strategy; it depends on and uses the relevant analysis and work already completed. It presents tactical guidance on all the vital basics for Egypt to adopt in order to accomplish its economic and social aims and to improve a sustainable growth rapidly. The refreshed strategy provides a number of innovative or reviewed themes, methodologies, concepts, and best practices that are vital to Egypt achieving its tourism goals: (Egyptian national competitiveness council, 2013) a. "Developing and Managing Tourism for Economic and Social Success" The main idea of the strategy relies on tourism's economic profit that contribute to social success to personal skill development, to community and regional development, and to bring benefits to other sectors.

\section{b. The "Tourism Diamond" Methodology of Integrated Planning}

This methodology exposes the relationships inside the tourism sector structure and shows how they interconnect. Keeping in mind the end goal to make progress of the general methodology, every one of these components must be incorporated in its arranging and usage.

\section{c. The "Tourism Platform Concept"}

This idea indicates how the information components required to drive tourism merge to produce a strong platform for economic benefits. This platform produces a range of outputs in a variety of topics relating to tourism, and supporting sectors that depend partly on tourism. 


\section{d. The "Destination within the Destination" Strategy}

This plan encourages the creation of five major destination areas. These areas are sub-destinations that support economic return. This approach will help allocate tourism benefits within Egypt and present a greater diversity of distinguished products and services to its markets and customers. International airports will serve the whole destination. Normal boundary will supply new chances for promotion and marketing innovation.

\section{e. Marketing}

The value proposal of the refreshed strategy must be characterized by diversity in development in order to enlarge and satisfy its appeal to a variety of target customers. Marketing should expand internationally in order to attract the market share. Strategic proposals will involve the selection of new efficient approaches supported by scientific researchs to support decision-making. Thus realized the competitive advantage of a destination through innovation and investment.

\section{f. Development}

The key vital messages for development concentrate on the criticality of value, visitor experience, and the need for innovation, the innovative heritage civilization, uniqueness in new development, and the ideal way to present the valuable coastal lands in a sustainable method.

\section{g. The Environment}

Tourism development must preserve and enhance environmental nature, which is a developing variable - mainly among European tourists - For the purpose of travel in general, and to make a decision for a specific destination in particular.

\section{h. Human Resources (HR)}

$\mathrm{HR}$ is a basis issue supporting to competitive advantage and the visitor experience. HR can affect social field positively. HR must be a high degree of skill and thus develop the sub-sectors in the tourism, such as Spa and Wellness Tourism, Leisure Center Management, Event Organization, and Catering and Animation. The strategy realizes that the current training system for tourism is not enough.

\section{i. Innovation}

Heritage and culture remains an essential motivation for visitation, nevertheless, it suffers a lack of innovation. The strategy calls for overcoming this challenge by the technical team from the Ministry of Tourism.

\subsection{SWOT Analysis for the Egyptian Tourism Strategy}

\subsubsection{Strengths: (Ragab, 2007).}

- Nearness to Europe and to Arab markets.

- Well established destination and airport network.

- Climate: Year-round excellent weather Egypt's weather gives a comparative advantage to other touristic destinations.

- Unique and distinctive culture and heritage that diversified tourism product, cultural and historical monuments, day and night recreation, diving, therapeutic, shopping, and residential and eco-tourism. 
- Price Competitiveness Competitive prices in hotel rooms and money value compared to other country in the region, especially in charges and ticket taxes.

- Excellent coastal and marine assets spectacular beaches, desert, and cruising.

2.3.2 Weaknesses: (Egyptian national competitiveness council, 2013).

- The inflexibility and routine of the institutional framework.

- Shortage of a strategic plan to collaborate the efforts of the public and private sectors.

- Lack of human resources development

- Ambiguity in the brand, value added, and shortage in Services quality.

- Investment climate.

- Reduction in financial resources for marketing and deficiency in marketing strategy.

- Insufficient market research, global marketing reach, and networks

- Inadequate infrastructure

- Seasonality

- Food handling

\subsubsection{Opportunities :( Ragab, 2007)}

- Developed internal distribution of tourism within the North Coast and Marsa Matrouh, Red Sea Area and some governorates in Upper Egypt like Sohag and Assuit can profit from the successful marketing efforts and well-established infrastructure (international airports) and the roads facilities.

- Community participation

- Legal reform and environmental regulation.

- Diversification of products

- The partnership of public and private sector

- HR Capacity Enhancement

- New Markets and niche markets

- Use of technology in marketing, product and experience development

- Utilize of social media

2.3.4 Threats: (Egyptian national competitiveness council, 2013).

- Political and Social instability

- Breakdown in Law and Order

- Budget Reductions

- Damage to Image and Brand

- Cost Increases

- Rationing of resources

- Cut prices because of marketing policies of competitors destinations

- Irregular traffic or traffic chaos

- Environmental Protection 


\subsection{Future Challenges and Potential Solutions in Egypt's Tourism}

The future of Egypt's Tourism face challenges as: (Egyptian national competitiveness council, 2013).

- Tourism development must be high quality to attract a great deal of investment. It must be creative enough to provide entertainments, while maintaining the ecological balance.

- Egypt will have to compete globally in areas of quality and value. Sustainable tourism will require luxury, keeping in mind customer satisfaction.

- Accommodations should support the development of a luxury. Hotels should offer innovation in field such as health care and security services and needs of people with mental and physical disabilities.

- Marketing tools and approach

- The good or positive visitor experience which satisfying multiple senses depending upon raise skill levels of staff.

- Cruising offers a unique experience with high quality standards.

- Green and sustainable buildings must be in harmony with nature.

- Hotel brands now provide opportunity for creativity and innovation.

\subsection{Delphi Characteristics}

The technique name is gotten from Greek myths, from the oracle located in Delphi, where a priestess - Pythia anticipated the future and gave suggestion about important decisions, such as the direction of military operations, from Apollo who spoke through her (Loo, 2002). The Delphi techniques have been referred and used from 1960s to 2013 in many fields. Previously, the word „Delphie was indicated to the traditional based Delphi technique. (Espinosa and Caro, 2011; Cole et al, 2013). Delphi approach can be divided into two methods. The first approach is a classical Delphi technique where experts apply the paper based communication channel to complete the surveys and the second methodology will be the use of the computer, internet, and other related IT technologies through their PC Delphi technique in which experts uses to perform the surveys (Lamichhane, 2014).

Moreover, Delphi is a boring process, consists of three to four rounds, concerning a sequence of questionnaires, each designed to build on the results of the previous survey. The results of each round are analyzed and returned to the experts. After progressive cycles, experts are able to re-examine their answers based on the answers of all participants. Names of the participants are known only to researchers but not necessarily to the other participants. Hence, not to mention the names of the participants prevents any of them from being influenced by the decision of the other (Somerville, 2008). 
Delphi is a qualitative technique combining the knowledge and opinions of experts to achieve a consensus opinion on a serious subject (Weber, Ladkin, 2003). Linstone and Turoff (2002) characterized it as an organized group communication process to guarantee the efficiency of scientists group who, try to overcome a complex problem. This is completed through repeated rounds, in which specialists are provided with questionnaires that build on the previous round results. This method provides valued and experienced discussions, which assist in providing the introduction of a number of opinions to the consensus (Powell, 2003; Briedenhann, Butts, 2006).

Although there is another way to reach consensus that has been studied but it has been found to be inappropriate to the progress of the objective indicators. These comprise of nominal groups (Carney et al., 1996), focus groups (Morgan, 1997) brainstorming (Hasson et al., 2000), technique (Lai et al., 2002), analytic hierarchy process (AHP) and the establishment of working groups. The main disadvantages with each of these approaches is their danger of considering just of the impression of the most frank or prejudiced members of that group or of only concentrating on attractive or contentious factors (Fein et al., 1997).

\subsubsection{The basic four key features of the Delphi method}

The basic four key features of the Delphi method are:

1- Anonymity: is defined as enable a group of experts to express their opinions through the questionnaires without familiarizes them with the identities of each other. Delphi anonymity decreases the leading influences within specialists and social pressures to make the confirmation, compared to other type of formal communication methods as face-to-face communication. Decisions are based on their personal view and not on the proposed idea (Lamichhane, 2014).

2- Repeatability: Enable participants to adjust their opinions based on the result of the group in the next round (Loo, 2002; Skulmoski et al., 2007).

3- Controlled feedback: Controlled repeated feedback helps the specialists to highlight their response based upon the other experts' opinions as feedback in a recurring pattern. Experts get this feedback from the summary report, which include quantitative estimated data extract from experts' responses. (Lamichhane, 2014), It offers participants the point of view of other experts and giving them an opportunity to clarify and modify their opinion (Loo, 2002; Skulmoski et al., 2007).

4- Statistical group response provides an opportunity to analyze and explain the quantitative information. It has many advantages such as reducing the bias for a particular opinion, less appropriate communication, and the lack of group pressure to reach conformity (Lamichhane, 2014) the statistical group responses provides data explanation and data analysis (Loo, 2002; Skulmoski et al., 2007). 


\section{Methodology}

The research focus of this study aimed at using Delphi methods as a tool to measure the efficiency of the Refreshed Tourism Strategy 2013-2020 for the tourism in Egypt. Focusing on the Refreshed Tourism Strategy 2013-2020 and its new themes, and concepts that are essential to Egypt achieving its tourism aims. Moreover, the Delphi technique with the procedure of system detailing, on account of which the procedure will include the generally comprehended specialists and partners of the tourism business in Egypt.

The examination procedure, using the Delphi strategy, depends on four steps: (Ballantyne \&et al., 2016)

The first step started with the determination of specific experts who would fill in the questionnaire and give their view related to a specific topic to the researchers. The second step the researchers collected and analyze these questionnaires according to experts' impression of significance. The third step a follow-up questionnaire send to the specialists reflecting the results of agreement of the previous questionnaire. Elements, which have minimum agreement according their significance, are excluded from the next questionnaire. Then the updated form of questionnaire is re-sent to the experts. The fourth step specialists are requested again to determine the most important elements in the survey in the light of the results of the previous round. All following repetition is the process of purification and filtering all the elements of the topic and questionnaire to deepen the subject. Delphi techniques act as a criticism to direct experts toward the most distinguished elements they are review. This process is repeated until the researchers reached a solution.

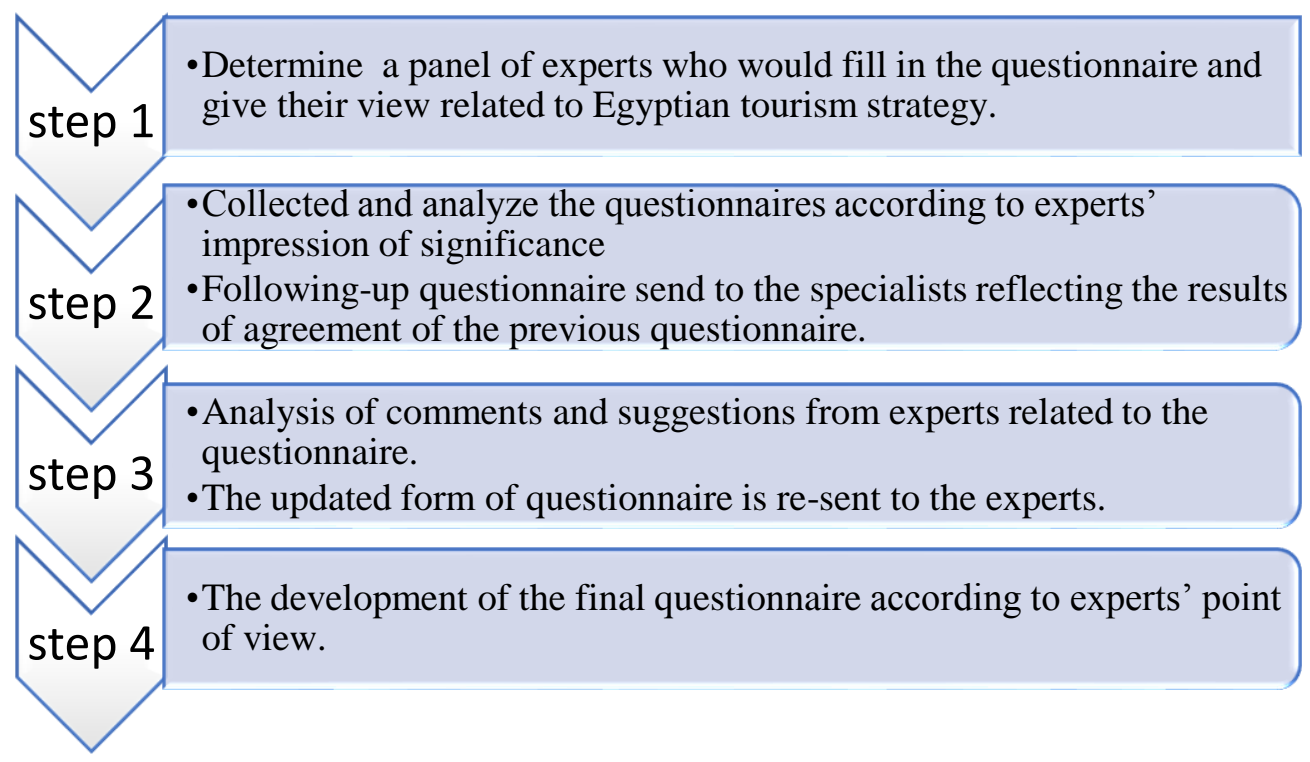

Figure 1. The methodology of Delphi methods

\subsection{Respondents}

The size of Delphi panels reported in past studies covers a wide range from tens to hundreds. The choice depends on the nature, scope, and importance of the study. 
Dalkey (1969) contends that 15-20 members are the minimum number of respondents needed. Martino (1983) indicates that expertise and knowledge on the subject matter is the most important criterion for a Delphi study. Several published studies, such as those by Sackman (1975) and Welty (1974), show that high levels of expertise are not necessary for a quality forecast. Previous research employing the Delphi technique has demonstrated that three-round Delphi iteration is sufficient to gain a high degree of group consensus (Green et al., 1990). The mail survey was the main form of data collection. Data collection was carried out during the period from Jan 2017 to May 2017. Therefore, in the first round, 100 questionnaires were sent out to a list of experts from tourism industry and experts from another seven fields such as science, administration, government, non-governmental organization, protected areas, cultural institution, and media in Egypt via e-mail; 82 responses were received. The first round includes general questions regarding the tourism strategy. These questions created in the form of surveys and the results analyzed and summarized. All the inappropriate answers are to be excluded and only the important ones remain. All the common ideas and viewpoints are collected and gathered in the report. The second round goes somewhat more profound into the point. The answers will clear up different issues in the questionnaire and the overviews. The second round went to the same list, of those who completed the first round, only 72 responded to the second round. The third round and the final questionnaire round where all the reports can be arranged for the decision making process. This questionnaire was sent to the same list of experts with response of 95\% responded. Mitchell, (1991) Also, found that the more the members differed, the larger the group should be. It appears that panels of experts who also have diversity in specialization are more accurate judgments than experts who are more homogeneous (Powell, 2003). Consequently, list of experts included tourism industry and experts from another seven fields such as science, administration, government, nongovernmental organization, protected areas, cultural institution, and media in Egypt.

Most studies use panels of 15 to 35 experts, although in some applications hundreds, even thousands of respondents have been involved. The length of the invitation list should anticipate an acceptance rate of between 35 and 75 percent (Gordon, 1994). Finally, as the number of rounds increases and the effort required by Delphi participants, one often sees a fall in the response rate (Alexander, 2004).

\subsection{Instrument}

The data collecting method of the study was questionnaire. A few interviews were performed with experts to verify the gathered data. A pilot study was conducted to test the questionnaire validity. Reliability analysis on item-scale was conducted. In the questionnaire, Cronbach's alpha of the study measures were above 0.70 . The questionnaire was prepared based on the Likert's 5 -scale model. The questionnaire comprises of five sections. Section 1 consists of nine inquiries to measure the efficiency of some elements (The nine factors that make up the refreshed version" of the 2008/9 National Tourism Strategy) for 
the Egyptian tourism strategy with five point scale ranging from not important (1) to extremely important (5). The higher score of the five point Likert scale means the higher efficiency of some elements for tourism development. Section 2 consists of five statements to measure factors contribute to the Implementation with five point scale ranging from not important (1) to extremely important (5). The higher score of the five point Likert scale means the higher level of factors contribute to the Implementation. Section 3 consists of 8 statements to measure barriers to the Implementation with five point scale ranging from not important (1) to extremely important(5). The higher score of the five point Likert scale means the higher barriers to the Implementation. Section 4 consists of six inquiries to determine the measures necessary for Implementation with five-point scale ranging from not important (1) to extremely important (5). The higher score of the five point Likert scale means the higher measures necessary for Implementation. Section 5 is the respondents' profile.

\subsection{Measures}

The refreshed strategy provides a number of innovative or reviewed themes, methodologies, concepts, and best practices that were measured using revised items from Egyptian national competitiveness council,(2013). These elements are:

a. "Developing and Managing Tourism for Economic and Social Success"

b. The "Tourism Diamond" Methodology of Integrated Planning

c. The "Tourism Platform Concept"

d. The "Destination within the Destination" Strategy

e. Marketing

f. Development

g. The Environment

h. Human Resources (HR)

i. Innovation

\subsection{Data analysis}

Data was analyzed using SPSS version 16 software package. The suitable tools were used to test the hypotheses and find the reliability. Cronbach's alpha was used to test the reliability of the data, the mean and standard deviation have been calculated to classify the sets and determine how homogenous or discrepant (inconsistent) the sample is, regarding all research variables. A correlation analysis was then conducted to find out the relationship between study variables. Moreover, regression analysis was conducted to measure the efficiency of the elements for tourism strategy through Delphi methods.

\section{Results}

\subsection{Respondent Profile}

Respondents' demographic data were analyzed by descriptive statistics using the SPSS 16. Table (1) shows the demographic profile of respondents. Female respondents' represents (32.9\%) slightly outnumbered their male counterparts $(67.1 \%)$. Most respondents were relatively young. About $(12.2 \%)$ of the respondents were above the age of 50, with almost half of the sample (46.3\%) falling into the age category of 24-30. 
In terms of work experience, nearly half of the respondents (48.8\%) falling into the range from one year to five years. While (11\%) of the respondents have experience ranged from six to ten years, moreover the work experience of $(40.2 \%)$ of the sample was more than sixteen years of work experience.

\section{Table 1: The Profile of the Respondents}

\begin{tabular}{|l|c|c|c|c|c|c|}
\hline & \multicolumn{2}{|c|}{ Round 1 } & \multicolumn{2}{c|}{ Round 2 } & \multicolumn{2}{c|}{ Round 3 } \\
\hline Variable & Sample & Percentage & Sample & Percentage & Sample & Percentage \\
\hline Gender & & & & & & \\
\hline$\square$ Female & 51 & 62.2 & 37 & 51.4 & 27 & 32.9 \\
\hline$\square$ Male & 31 & 37.8 & 35 & 48.6 & 55 & 67.1 \\
\hline Age & & & & & & \\
\hline$\square 24-30$ & 39 & 47.6 & 37 & 51.4 & 38 & 46.3 \\
\hline$\square 31-40$ & 32 & 39.0 & 27 & 37.5 & 34 & 41.5 \\
\hline$\square 41-50$ & 3 & 3.7 & 0 & 0 & 0 & 0 \\
\hline$\square$ more than & 8 & 9.8 & 8 & 11.1 & 10 & 12.2 \\
\hline experience & & & & & & \\
\hline$\square 1-5$ years & 57 & 69.5 & 51 & 70.8 & 40 & 48.8 \\
\hline$\square-10$ years & 11 & 13.4 & 9 & 12.5 & 9 & 11 \\
\hline$\square 11-15$ years & 0 & 0 & 0 & 0 & 0 & 0 \\
\hline$\square 16$ years & 14 & 17.1 & 12 & 16.7 & 33 & 40.2 \\
\hline
\end{tabular}

Then, descriptive statistics, which incorporate the mean and standard deviation, in table (2) have been calculated to order the sets and find out how homogenous or discrepant the sample is, concerning all research variables. The mean value for the third round was ranged from 3.659 to 5.00 and the standard deviation from 0.473 to 0.824 .

\section{Table (2) Mean and Standard Deviation for the study variables}

\begin{tabular}{|c|c|c|c|}
\hline & \multicolumn{2}{|c|}{3 Round } \\
\hline & & Mean & SD \\
\hline \multicolumn{2}{|r|}{ Factor 1: The efficiency of some elements for Tourism Strategy. } & 4.071 & .189 \\
\hline 1 & $\begin{array}{l}\text { Tourism development strategies has an influence on quality of life of the } \\
\text { inhabitants and the socio-economic development of the country and contribute to } \\
\text { social equity and inclusiveness. (The overall strategy's theme) }\end{array}$ & 4.012 & .824 \\
\hline 2 & $\begin{array}{l}\text { A strong platform for economic stimulus produces a range of outputs in a } \\
\text { diversity of themes relating to tourism.( The Tourism Diamond methodology ) }\end{array}$ & 4.329 & .473 \\
\hline 3 & $\begin{array}{l}\text { The relationships within the tourism sector framework and demonstrations must } \\
\text { be integrated in its planning and implementation.(The Tourism Platform Concept) }\end{array}$ & 3.987 & .824 \\
\hline 4 & $\begin{array}{l}\text { All the five destinations areas within Egypt can be served directly by } \\
\text { international air carriers. This will provide new opportunities for direct marketing } \\
\text { and marketing innovation .International marketing and product development. } \\
\text { (The Destination-within-the-Destination Strategy) } \\
\text {.( The Destination-within-the-Destination Strategy proceed in an integrated way. }\end{array}$ & 3.659 & .477 \\
\hline 5 & $\begin{array}{l}\text { The value proposition of the refreshed strategy must be diversified on the } \\
\text { development side in order to expand and elaborate its appeal to various target } \\
\text { groups. Marketing must extend globally in order to capture the market. } \\
\text { (Marketing) }\end{array}$ & 4.00 & .000 \\
\hline 6 & $\begin{array}{l}\text { development focus quality, the visitor experience, the need for innovation, the } \\
\text { need to leverage the great legacy of heritage civilization in new ways, the advice } \\
\text { to avoid sameness in new development, and the need to optimize the extremely } \\
\text { valuable coastal lands in a sustainable way.( Development) }\end{array}$ & 4.00 & .000 \\
\hline 7 & $\begin{array}{l}\text { Protective environmental practices are increasingly influencing destination } \\
\text { decisions - particularly among Europeans. (The Environment) }\end{array}$ & 4.00 & .000 \\
\hline 8 & $\begin{array}{l}\text { HR contributes to visitor experience, hence is a potential competitive advantage. } \\
\text { An HR strategy can also enhance social impacts for Egypt's communities. } \\
\text { (Human Resources (HR) }\end{array}$ & 4.329 & .473 \\
\hline
\end{tabular}




\begin{tabular}{|c|c|c|c|}
\hline 9 & $\begin{array}{l}\text { Egypt's heritage assets are great and powerful stories that need to be approached } \\
\text { in new, innovative ways.( Innovation) }\end{array}$ & 4.329 & .473 \\
\hline \multicolumn{2}{|r|}{ Factor 2: factors contribute to the implementation } & 4.402 & .284 \\
\hline 10 & $\begin{array}{l}\text { Public-Private Sector Partnership and well- functioning local and regional } \\
\text { authorities. }\end{array}$ & 4.329 & .473 \\
\hline 11 & Favorable state tourism policy. & 4.329 & .473 \\
\hline 12 & Development in the tourism infrastructure, including transport. & 4.329 & .473 \\
\hline 13 & High availability of financial capital. & 4.329 & .473 \\
\hline 14 & $\begin{array}{l}\text { Educational system conducive to development of innovation and } \\
\text { Entrepreneurship. }\end{array}$ & 4.670 & .473 \\
\hline 15 & Stable legal and administrative system. & 4.342 & .477 \\
\hline 16 & Egypt needs to become competitive on the Internet. & 4.342 & .477 \\
\hline \multicolumn{2}{|r|}{ Factor 3: Barriers to the implementation } & 4.249 & .103 \\
\hline 17 & $\begin{array}{l}\text { Training for employment and skills development is clearly a critical part of the } \\
\text { strategic solution. To be effective, training must be responsive to the changing } \\
\text { requirements of the sector. }\end{array}$ & 4.342 & .477 \\
\hline 18 & Lack of cooperation in the trade of business- science-government & 3.659 & .477 \\
\hline 19 & $\begin{array}{l}\text { Lack of a Specific Plan to carrying out the efforts of the Public and Private } \\
\text { Sectors. }\end{array}$ & 4.00 & .000 \\
\hline 20 & Poorly development tourism infrastructure (health resort, airport,etc.) & 4.00 & .000 \\
\hline 21 & Budget reductions and limited financial resources of tourism entrepreneurship. & 4.00 & .000 \\
\hline 22 & Social Unrest and low social competence. & 4.329 & .473 \\
\hline 23 & Problems with the implementation of innovative products/services/technologies & 5.00 & .000 \\
\hline 24 & Lack of a niche tourism offer. & 4.659 & .477 \\
\hline \multicolumn{2}{|r|}{ Factor4: Measures necessary for implementation } & 4.384 & .439 \\
\hline 25 & Strengthening the support of local, regional and international authorities. & 4.659 & .477 \\
\hline 26 & Development of infrastructure, including transport infrastructure. & 4.659 & .477 \\
\hline 27 & Strengthening cooperation between business and science. & 4.00 & .817 \\
\hline 28 & Increasing the availability of funds for the development of tourism. & 4.329 & .473 \\
\hline 29 & Introduction of appropriate legal, economic, and administrative mechanisms. & 4.00 & .817 \\
\hline 30 & $\begin{array}{l}\text { Adapting the educational system and lifelong learning to the needs of the tourism } \\
\text { industry. }\end{array}$ & 4.659 & .477 \\
\hline
\end{tabular}

Tabulated data in table (3) gave an indication of the nine elements of the refreshed vision of the tourism strategy by applying weighted mean and rank, it was found out that The Tourism Diamond methodology, Human Resources (HR), and Innovation are ranked as the most likely factors. The overall strategy's theme came second, followed by Marketing, Development, and The Environment as third elements; The Destination-within-the-Destination Strategy came in the fourth rank. The Tourism Platform Concept was the last.

Table (3) Mean and ranks for the study variables

\begin{tabular}{|l|l|c|c|}
\hline & \multicolumn{1}{|c|}{ Factors } & Mean & Rank \\
\hline 1 & $\begin{array}{l}\text { Tourism strategies has an influence on quality of life of the inhabitants } \\
\text { and the socio-economic development of the country and contribute to social equity } \\
\text { and inclusiveness.(The overall strategy's theme) }\end{array}$ & 4.012 & 2 \\
\hline 2 & $\begin{array}{l}\text { A strong platform for economic stimulus produces a range of outputs in a diversity of } \\
\text { Themes relating to tourism.( The Tourism Diamond methodology ) }\end{array}$ & 4.329 & 1 \\
\hline 3 & $\begin{array}{l}\text { The relationships within the tourism sector framework and demonstrations must be } \\
\text { Integrated in its planning and implementation.(The Tourism Platform Concept) }\end{array}$ & 3.987 & 5 \\
\hline
\end{tabular}




\begin{tabular}{|c|l|c|c|}
\hline 4 & $\begin{array}{l}\text { All the five destinations areas within Egypt can be served directly by international air } \\
\text { carriers. This will provide new opportunities for direct marketing and marketing } \\
\text { innovation .International marketing and product development -- proceed in an } \\
\text { integrated way.(The Destination-within-the-Destination Strategy) }\end{array}$ & 3.659 & 4 \\
\hline & $\begin{array}{l}\text { The value proposition of the refreshed strategy must be diversified on the } \\
\text { development side in order to expand and elaborate its appeal to various target groups. } \\
\text { Marketing must extend globally in order to capture the market.(Marketing) }\end{array}$ & 4.00 & 3 \\
\hline 6 & $\begin{array}{l}\text { development focus quality, the visitor experience, the need for innovation, the need to } \\
\text { Leverage the great legacy of heritage civilization in new ways.( Development) }\end{array}$ & 4.00 & 3 \\
\hline 7 & $\begin{array}{l}\text { Protective environmental practices are increasingly influencing destination decisions } \\
\text { - particularly among Europeans.(The Environment) }\end{array}$ & 4.00 & 3 \\
\hline 8 & $\begin{array}{l}\text { HR contributes to visitor experience, hence is a potential competitive advantage. An } \\
\text { HR strategy can also enhance social impacts for Egypt. (Human Resources (HR) }\end{array}$ & 4.329 & 1 \\
\hline 9 & $\begin{array}{l}\text { Egypt's heritage assets are great and powerful stories that need to be approached in } \\
\text { Innovative ways.( Innovation) }\end{array}$ & 4.329 & 1 \\
\hline
\end{tabular}

The reliability analysis was performed for measuring the reliability of variables as the efficiency of some elements for Tourism strategy; factors contribute to the implementation, Barriers to the implementation, and Measures necessary for implementation in order to know to what extent these items have an internal consistency. Cronbach's alpha should meet the recommended significance of 0.70 or higher ((Nunnaly, 1978).

The results of the reliability analysis are presented in Table (4). As the table shows, the reliability analysis gave alpha coefficients exceeding (.70), for the constructs, which are regarded as acceptable reliability, coefficients and a good indication of construct reliability.

Table (4): The measuring constructs reliability

\begin{tabular}{|c|l|c|}
\hline $\mathbf{N}$ & \multicolumn{1}{|c|}{ Construct } & Cronbach's Alpha \\
\hline $\mathbf{1}$ & The efficiency of some elements for Tourism strategy. & \multirow{2}{*}{0.743} \\
\cline { 1 - 2 } $\mathbf{2}$ & Factors contribute to the implementation. & \\
\hline $\mathbf{3}$ & Barriers to the implementation. & \\
\hline $\mathbf{4}$ & Measures necessary for implementation. & \\
\hline
\end{tabular}

A correlation analysis was conducted to find out the relationship between the efficiency of some elements for tourism strategy (F1), Factors contribute to the implementation (F2), Barriers to the implementation (F3), Measures necessary for implementation (F4). The results indicated in (Table 5) showed that there is a positive correlation between F1, F2, F3, and F4; the four variables were positively correlated. $(\mathrm{r}=0,600$ and $\mathrm{p}<0.5)$. The findings of the path analysis demonstrated that a positive relationship was found between (The efficiency of some elements for tourism, factors contribute to the implementation, Barriers to the implementation and Measures necessary for implementation).

Table (5) Correlations among the Study Variables

\begin{tabular}{|l|l|l|l|l|}
\hline \multicolumn{1}{|c|}{ Variables } & \multicolumn{1}{|c|}{$\mathbf{1}$} & \multicolumn{1}{|c|}{$\mathbf{2}$} & \multicolumn{1}{|c|}{$\mathbf{3}$} & $\mathbf{4}$ \\
\hline 1. The efficiency of some elements for tourism. & 1 & & & \\
\hline 2- factors contribute to the implementation. & $0.267^{*}$ & 1 & & \\
\hline 3- Barriers to the implementation. & $0.961^{*}$ & $-0.010-$ & 1 & \\
\hline 4- Measures necessary for implementation. & $0.996^{*}$ & $0.349^{*}$ & $.934^{*}$ & 1 \\
\hline
\end{tabular}

* Correlation is significant at the 0.05 level. 
Moreover, a regression analysis was conducted and the $\mathrm{R} 2$ values were used in order to find out what amount of total change in the dependent variable was due to the independent variable dimensions. The determination factor was found to be R2: 0.352 , which showed that $35 \%$ of the impact of the tourism development on specified aspects was dependent on factors, contribute to the implementation. The results of the regression analysis can be summarized as in table (6)

Table (6): Regression Analysis

\begin{tabular}{|l|c|c|c|c|c|}
\hline Independent variable & \multicolumn{5}{|c|}{ Dependent variable } \\
\hline $\begin{array}{l}\text { factors contribute to the } \\
\text { implementation }\end{array}$ & \multicolumn{4}{|c|}{ The efficiency of some elements for tourism } \\
\cline { 2 - 6 } & $\beta$ & $\mathrm{T}$ & $\mathrm{Sig}$. & $\mathrm{F}$ & $\mathrm{R}^{2}$ \\
\cline { 2 - 6 } & .593 & 6.715 & 0.016 & 6.117 & .352 \\
\hline
\end{tabular}

\section{Discussion and Conclusion}

This study aimed at using Delphi method in the process of measuring the efficiency of the Refreshed Tourism Strategy 2013-2020 for the tourism development in Egypt. This refreshed strategy provides strategic guidance on all the critical essentials for Egypt to adopt in order to attain its economic, cultural, social, and environmental aspects. Consequently, sustainable growth will recover as quickly as possible.

Furthermore, the results of this study revealed that experts who have 1-5 years and 6-10 years of experience have largely participated in the study.

Based on the questionnaire results, the ranks of the nine factors of the Refreshed Tourism Strategy 2013-2020 are: The Tourism Diamond methodology, Human Resources (HR), and Innovation are ranked as the first due to their importance. This is in line with the result of Sustainable Development Strategy, which confirmed that, by 2030, the administration system of Egypt would be more efficient and flexible, the ability to maximizing resources, providing product with high quality services, the ability to use advanced techniques, and applies a legislature fair system. Therefore, these elements should contribute to the economic growth (COMCEC, 2015). Moreover, Attia (1999) said that Egypt compete globally in areas of quality and value to achieve competitive advantage in the field of tourism. Taking into consideration Luxury, and customer satisfaction which are a prerequisite needs for sustainable tourism.

The highest value for the mean of F2 and F3 were (Educational system conducive to development of innovation and Entrepreneurship), and (Problems with the implementation of innovative products/services/technologies). The two elements consistent with the tourism plan. As, the government implemented number of investments that achieving developing infrastructure, establish investment projects that contribute economic growth, and raise the employment rate, especially for youth and females. (COMCEC, 2015). Moreover, the tourism policy suggested innovative tourist product. It provided several activities including several types of tourist accommodation and services, sports activities, maritime centers, exhibition and festival halls, 
conference centers, shopping centers, War museums, safaris, and many other different tourist activities. However, some of these activities have not yet been implemented or replaced (Attia, 1999).

Another significant result of the current study was that a positive relationship was found between (The efficiency of some elements for tourism F1, factors contribute to the implementation F2, Barriers to the implementation F3 and Measures necessary for implementation F4).

According to regression analysis, the determination factor was showed that $35 \%$ of the efficiency of some elements for tourism was dependent on factors that contribute to the implementation. Attia (1999) confirmed that The Egyptian tourism policy should be perfectly implemented in close cooperation with business, science, and administration. Policymakers should direct the local community, to produce innovative tourism products and services. Furthermore, policy development and implementation of sustainable tourism have to be recognized as an essential element of the policy process. They should be a prerequisite need and not a slogan. Therefore, all tourism activities must planning, design and development with active cooperation from all interested and involved parties, particularly the private sector and local communities. Research results reported that experts pointed to the efficiency of the nine elements of the tourism strategy. However, they pointed out to the lack of strategic importance, and the need for the involvement of tourism investments in Egypt.

\section{Further research}

The use of the Delphi method in building the vision of the future development of tourism in Egypt will be the basis for the verification of the structure and the correct application of the prepared research tool, and will indicate the potential for future research.

\section{References}

Alexander, D. C. (2004). A Delphi study of the trends or events that will influence the future of California charter schools. Digital Abstracts International, 65 (10), 3629. available at: http://www.fepto.com/wp-content/uploads/Delphi-method-forGraduate-research.pdf (Accessed on 22 Mar 2015).

Attia, A.,(1999),Planning For Sustainable Tourism: An Investigation into Implementing Tourism Policy In the North West Coast Region of Egypt available at: https://www .cpasegypt.com/.../PhD\%20Planning\%20for\%20Sustainable\%20Tourism.pdf...(Access ed on 26 Feb 2017).

Ballantyne R., Hughes K., Bond N. (2016) Using a Delphi approach to identify managers' preferences for visitor interpretation at Canterbury Cathedral World Heritage Site available at: https://www.ijsr.net/archive/v5i5/21051602.pdf. (Accessed on 26 Feb 2017).

Briedenhann J., Butts S. (2006), The application of the Delphi technique to rural tourism project evaluation, Current Issues in Tourism 9 (2), pp. 171-190 available at: https://www isiarticles.com/bundles/Article/pre/pdf/65175.pdf(Accessed on 20 Mar 2015)

Carney, O., McIntosh, J. and Worth, A. (1996) 'The use of the nominal group technique in research with community nurses', Journal of Advanced Nursing 23,5, 
$1024-1029$

available

at

http://www.southampton.ac.uk/assets/centresresearch/.../Nominal\%20Group\%20T echnique(Accessed on 20 Mar 2015)

Cole, Z. D., Donohoe, H. M., and Stellefson, M. L. (2013). Internet-Based Delphi Research: Case Based Discussion. Environmental management, 1-13 available at : http://www.sciencedirect.com/science/article/pii/S1878029615006386(Accessed on $26 \mathrm{Feb} 2017)$.

COMCEC, (2015) Effective Tourism Marketing Strategies:ICT-Based Solutions for the OIC Member Countries,Standing Committee for Economic and Commercial Cooperation of the Organization of Islamic Cooperation COMCEC

OFFICE .available

at: https://www.mod.gov.tr/.../Effective\%20Tourism\%20Marketing\%20Strategies, \%2 OICT-Base. (Accessed on 18 Mar 2015)

Dalkey, N.C. (1969), Delphi Method: An Experimental Study of Group Opinion, The Rand Corporation, Chicago, IL. available at:

https://www.rand.org/content/dam/rand/pubs/research_memoranda/2005/RM5888. pdf...(Accessed on $26 \mathrm{Feb} 2017$ ).

Egyptian national competitiveness council, (2013) Refreshed Tourism Strategy 2013-2020 The Way Forward and New Horizons available at : http//www.encc.org.eg/download.php?...Refreshed\%20Tourism\%20Strategy\%202 013-202(Accessed on $26 \mathrm{Feb} 2016$ ).

Espinosa, K., and Caro, J. (2011), A real-time web-based Delphi study on ICT integration framework in basic education. In proceeding of CSIT International Conference on Telecommunication Technology and Applications (pp. 223-228). available at : http//www. jultika.oulu.fi/files/nbnfioulu201402081077.pdf(Accessed on 26 Feb 2016).

Fein, J.A., Lavelle, J.M., Ginsburgt, K.R. and Giardino, A.P. (1997) 'A methodology to maximize resident input in improving a pediatric rotation' Arch. Pediatr.Adolesc. Med. 151 840-844. available at: https://biblio.ugent.be/publication/5933151/file/5933182(Accessed on 26 Feb 2016).

Gordon Theodore J.( 1994 ) THE DELPHI METHOD The Millennium Project Futures Research Methodology - V3.0 available at :https:/www millenniumproject.org/FRMv3 0/04-Delphi.pdf(Accessed on 26 Feb 2016).

Government of Egypt,(2015), Sustainable Development Strategy: Egypt's Vision 2030) available at: http/l www.unosd.org/.../1271Egypt_Dr.\%20Nihal\%20El\%20Megharbel_Workshop\%2 0on(Accessed on 20 Mar 2015).

Green, H., Hunter, C., \& Moore, B. (1990). Assessing the environmental impact of tourism development: use of the Delphi technique. Tourism Management, 11(2),111-120. available at: https://www.mdpi.com/20711050/6/12/8980/pdf(Accessed on 26 Feb 2016).

Hasson, F., Keeney, S. and McKenna, H. (2000) 'Research guidelines for the Delphi survey technique', Journal of Advanced Nursing 32(4) 1008-1015. available at: https://www pareonline.net/pdf/v12n10.pdf(Accessed on 26 Feb 2016).

Kiryluk H. (2009), Rola samorządu terytorialnego w zarządzaniu turystyka na obsza-rach przyrodniczo cennych, in: W. Chiżniak, T. Ołdytowski, E. Szymańska 
(eds.), Tu-rystyka i rekreacja na obszarach przyrodniczo cennych w regionach transgranicznych północno-wschodniej Polski, Oficyna Wydawnicza Politechniki Białostockiej, Biały-stok, pp. 53-68 available at: http// www.yadda.icm.edu.pl/yadda/element/bwmeta1.../c/szpilko the use 4 2014.pdf. pdf (Accessed on 20 Mar 2015)

Lai, V.S., Wong, B.K. and Cehung, W. (2002) 'Group decision making in a multiple criteria environment: A case using the AHP in software selection', European Journal of Operational Research 137 134-144. available at: http// www.websm.org/.../Group decision_making_in_a multiple_criteria_environment A

Lamichhane D.( 2014) Design of Delphi technique integrated with social media to make consensus based on expert s' opinion Oulu, January 30, University of Oulu Department of Information Processing Science Mastere"s Thesis available at: http// www. jultika.oulu.fi/files/nbnfioulu-201402081077.pdf(Accessed on 20 Mar 2015)

Linstone H.A., Turoff M. (2002), Introduction, in: H.A. Linstone, M. Turoff (eds.), The Delphi Method: Techniques and Applications, Murray Turoff and Harold A. Linstone, pp. 3-5 available at: http// www citeseerx.ist.psu.edu/viewdoc/download?rep=rep1\&type=pdf\&doi=10.1.1

Loo R. (2002), The Delphi method: a powerful tool for strategic management, Policing: An International Journal of Police Strategies Management 25 (4), pp. 762-769 available at: http// www jem.pb.edu.pl/data/magazine/article/440/en/3.3_szpilko.pdf(Accessed on $20 \mathrm{Mar}$ 2015)

Martino, J.P. (1983), Technological Forecasting for Decision Making, American Elsevier, New York, NY. Ministry of tourism (2010), Ivest in Egypt available at : http://www.sis.gov.eg/PDF/Ar/1/4.pdf (Accessed on 20 Mar 2015).

Mitchell, V. W. (1991). The Delphi technique: An exposition and application. Technology Analysis \& Strategic Management, 3(4), 333-358.

Morgan, D.L. (1997) Focus Groups as Qualitative Research. 2nd Edition. London:Sage. available at: http// www usir.salford.ac.uk/2268/1/FoucsGroupsPapeshouldber.pdf (Accessed on $25 \mathrm{Mar}$ 2015)

Nunnally, J. C. (1978). Psychometric theory (2nd ed.). New York, NY: McGrawHillYilmaz O., D., (2014) Perception of Organizational Politics and Impression Management Behaviors: A Tourism Industry Perspective , International Journal of Business and Social Science Vol. 5, No. 8; July 2014.available at: http://www.ijbssnet.com/journals/Vol_5_No_8 July_2014/10.pdf(Accessed on 24 May 2015).

Powell, C. (2003). The Delphi technique: Myths and realities. Journal of Advanced Nursing, 41(4), 376-382. Available at : http://www.onlinelibrary.wiley.com/doi/10.1046/j.13652648.2003.02537.x/abstract(Accessed on 25 Mar 2015)

Ragab, A. (2007), Assessment of Trade in Tourism and Travel Related Services in Egypt in Relation to the Gats, Cairo - Egypt available at: http://www.tas.gov.eg/NR/rdonlyres/91D361E8-44F0-45A08C19.../TourismStudy2.pdf(Accessed on 20 Mar 2015) 
Sackman, H. (1975), Delphi Critique: Expert Opinion, Forecasting and Group Process, D.C. Heath, Lexington, MA. available at: https://www.albany.edu/cpr/stewart/Papers/StewartDelphi1987.pdf(Accessed on 18 Mar 2015).

Skulmoski G.J., Hartman F.T., Krahn J. (2007), The Delphi Method for Graduate Re-search, Journal of Information Technology Education 6, pp. 1-21 available at :http://www.fepto.com/wp-content/uploads/Delphi-method-for-Graduateresearch.pdf(Accessed on 20 Mar 2015).

Sleiman, M. (2014), Egypt announces plans to revive flagging tourism sector. Reuters. available at: http://www.reuters.com/article/2014/05/04/us-egypt-tourismidUSBREA4305B20140504(Accessed on 18 Mar 2015).

Somerville , A.(2008),Effective Use of the Delphi Process in Research: Its Characteristics, Strengths, and Limitations. available at: https://www. jasomerville.com/wpcontent/uploads/2011/08/DelphiProcess080617b.pdf(Accessed on 18 Mar 2015). Swiss Economic Cooperation and Development, (2012), Egypt Country Strategy 2013-2016 available at : https://www.secocooperation.admin.ch/.../aegypten/SECO\%20Country\%20Strategy\% (Accessed on 22Mar 2015).

Weber K., Ladkin A. (2003), The convention industry in Australia and the United King-dom: Key Issues and Competitive Forces, Journal of Travel Research 42 (2), pp. 125-132 available at: isiarticles.com/bundles/Article/pre/pdf/65175.pdf (Accessed on 20 Mar 2015).

Welty, G. (1974), "Problems of Selecting Experts for Delphi Exercises", Academy of Management Journal, Vol. 15,pp. 121-4. available at: https://www www.wright.edu/ gordon.welty/Delphi 73.pdf (Accessed on 20 Mar 2015).
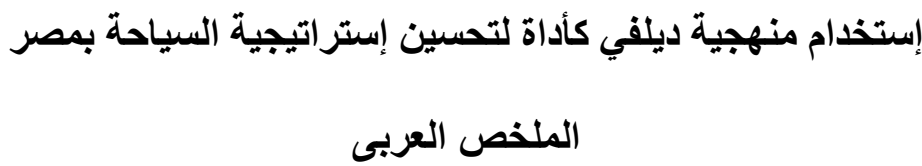

تعرض هذه الورقة نتائج دراسة استقصائية لمنهجية دلفي من ثلاث دورات أجريت عن طريق رأي

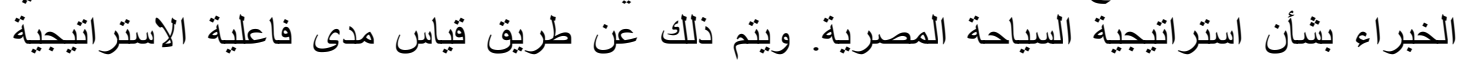
المتجددة للسياحة 2013-2020 في مصر. ولتحقيق هذا الغرض، استخدمت طريقة دلفي. ولقد أظهرت

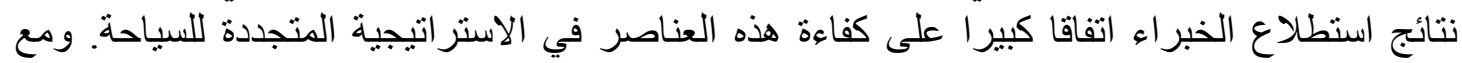

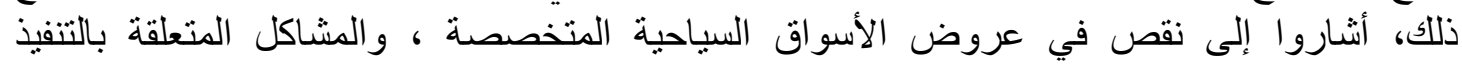
و الإبتكار بالنسبة للمنتجات / الخدمات / التكنولوجيات المبتوات التكرة، ونقص استر اتيجيات تدريب العمالة

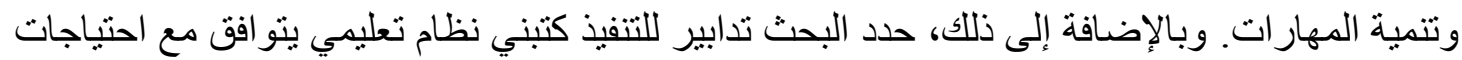

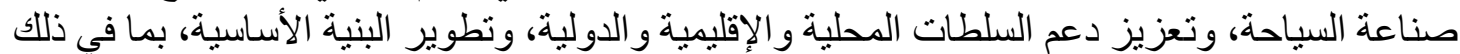
البنية الأساسية للنقل. 